\title{
Qualitative and semiquantitative analysis of magnetic lineaments in the Crystalline Basement Aquifer, Paraná - Brazil.
}

*Cássio de Almeida Pires1; Oderson Antônio de Souza Filho2; Gustavo Barbosa Athayde1.

${ }^{1}$ Hydrogeological Resarch Laboratory, Federal University of Parana (LPH-UFPR)

${ }^{2}$ Geological Survey of Brazil (CPRM)

Copyright 2019, SBGf - Sociedade Brasileira de Geofísica

This paper was prepared for presentation during the $16^{\text {th }}$ International Congress of the Brazilian Geophysical Society held in Rio de Janeiro, Brazil,19-22August 2019.

Contents of this paper were reviewed by the Technical Committee of the $16^{\text {th }}$ International Congress of the Brazilian Geophysical Society and do not necessarily represent any position of the SBGf, its officers or members. Electronic reproduction or storage of any part of this paper for commercial purposes without the written consent storage of any part of this paper for commercial purposes

\begin{abstract}
This work focus on the use Radially Averaged Power Spectrum (SPC) filters of airborne magnetic data to define qualitatively and semiquantitatively hydrogeological exploratory targets in the Crystalline Basement Aquifer of Paraná State, Brazil. The aquifer comprises the outcrop portion of the crystalline shield. Different enhancement methods were applied to the aeromagnetometric data, both from the main Total Magnetic Intensity (TMI) and the TMI from the magnetic sources at different depths generated by the SPC filters, in order to verify if the surface magnetic sources are attractive data. We evaluate that "shallow sources" and, what are conventionally called "noises", are not appropriate for the interpretation of the magnetic lineaments, nor the "deep sources". Nevertheless, the deep sources helped to understand the magnetic domains intrinsic of the regional geologic framework. For the interpretation of the lineaments, the most attractive product was the "intermediate sources". These sources were processed according to the following steps: Reduce to Pole (RTP); Tilt Angle (TDR) and Tilt Angle of Total Horizontal Derivative (TAHG) applications. A second map of lineaments was generated with the previous steps, however, preceded by the application of the Directional Cosine to the TMI data. The purpose is to reduce the strong magnetic effect of NW-SE structures, corresponding to the Dyke Swarms from the Ponta Grossa Arch. At the end, the lineaments were integrated, generating the magnetic framework of the corresponding aquifer.
\end{abstract}

\section{Introduction}

The use of aeromagnetometric data for geological studies of regional scale is already a routine, mainly focusing on the investigation of deep structures. Both the use of enhancement methods with Upward Continuation (WP), with various height simulations, and with the Radially Average Power Spectrum (SPC - Geosoft, 2001), using the deep sources, are used in this sense in several works. Few hydrogeological studies in Brazil have integrated airborne geophysics as a processing routine (e.g. Souza Filho et al., 2009).
The challenge is to evaluate if the local magnetic sources related to geological discontinuities, which we understood as potential exploratory targets for fractured aquifer, can be investigated using the SPC filters. Because the processing of this data can generate many noises, the use of the data has to be done with a lot of caution.

Crystalline Basement Aquifer (MMA, 2015) covers an area of $20,000 \mathrm{~km}^{2}$. It is part the plateau Primeiro Planalto Paranaense. The geological context of the this aquifer includes the Apiaí, Curitiba, Luíz Alves and Paranaguá Terranes; which are mainly composed igneous and highgrade metamorphic rocks in the southeast and low-grade metamorphic rocks portions to the north-northwest portion (Basei, 1992; Siga Jr., 1995; Salamuni, 1998; Cury, 2009). Dyke Swarms from the Ponta Grossa Arch (Almeida, 1967) significantly cut the present lithologies.

\section{Data}

The aquifer boundaries and outlines (Figure 1), together with the database of the tubular wells used, comes from the collection Carta das Águas do Paraná (MMA, 2015). This project was carried out in partnership with Ministry of the Environment (MMA), Geological Survey of Brazil (CPRM), Federal University of Parana (UFPR) and other institutions in the Parana State. The well's productivity ranges shown on the map are determined according to the parameters described in Diniz et al. (2014).

The aeromagnetic data was provided by the Geological Survey of Brazil (CPRM, 2011) from the Aerogeofísico Paraná - Santa Catarina Airbrone project. The survey was carried out with $500 \mathrm{~m}$ of flight lines spacing in N-S direction and $10 \mathrm{~km}$ of tie-line spacing in $\mathrm{E}-\mathrm{W}$ direction, with a $\sim 100 \mathrm{~m}$ of terrain clearance and $1 \mathrm{~s}$ of interval between the measures. To create the magnetic grids, we worked with a subset of the project data, comprising the study-area and used the Bi-directional interpolator (Geosoft, 2013), with a reasonable value of $1 / 5$ of flight space.

All processing steps were performed using the algorithms within Geosoft Oasis Montaj ${ }^{\text {tm }}$ v.9.2 and ArcGIS v. 10.5. All the program licenses and institutional support are from Laboratory for Research in Applied Geophysics (LPGAUFPR), Laboratory for Hydrogeological Research (LPHUFPR) and CPRM. 


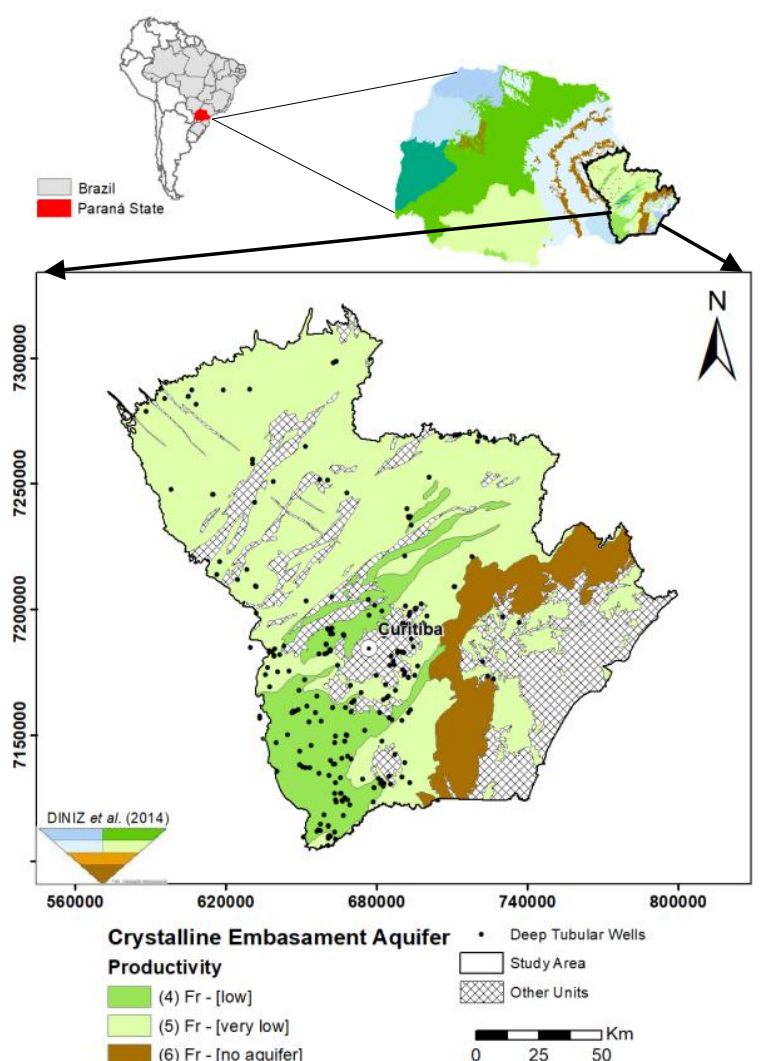

Figure 1 - Location and aquifer production of Crystalline Basement Aquifer (MMA, 2015). The productivity ranges are determined according to the parameters described in Diniz et al. (2014).

\section{Methods}

The well-data were organized in spreadsheets. The depth was the analyzed parameter to serve as reference and comparison with the depths of the magnetic sources.

The steps of the aeromagnetometric data processing followed two different paths and in the end, they were integrated (Figure 2). The SPC filter calculates the wavelengths (using the Equation 1) and depth of the main magnetic sources. These parameters are shownin. Two SPC graphs (semiquantitative analysis) which help choose the adequate band pass, low pass and high pass filters (Geosoft, 2001) according to the wavelengths calculated:

(Equation 1)

$$
W=(1 / K) * 10^{3}
$$

where, "K" is equal to the wavenumber; "103" is the transformation of units of measurements (kilometer to meter); and "W" is wavelength (value to be used in band pass, low pass and high pass filters).

The first SPC (SPC $\left.{ }^{1}\right)$ was generated from the first TMI (TMI $\left.{ }^{1}\right)$ and applied some enhancement methods (qualitative analysis), namely: Reduce to Pole - RTP (Grant \& Dodds, 1972; MacLeod et al., 1993; Li 2008), Tilt
Angle - TDR (Miller \& Singh, 1994) and Tilt Angle of Total Horizontal Derivative - ISA-GHT (Ferreira, 2010, 2013). For the second SPC $\left(\mathrm{SPC}^{2}\right)$, the same enhancement methods were also applied, but firstly a Directional Cosine filter (DC - Geosoft, 2001) was applied in the NW-SE orientation.

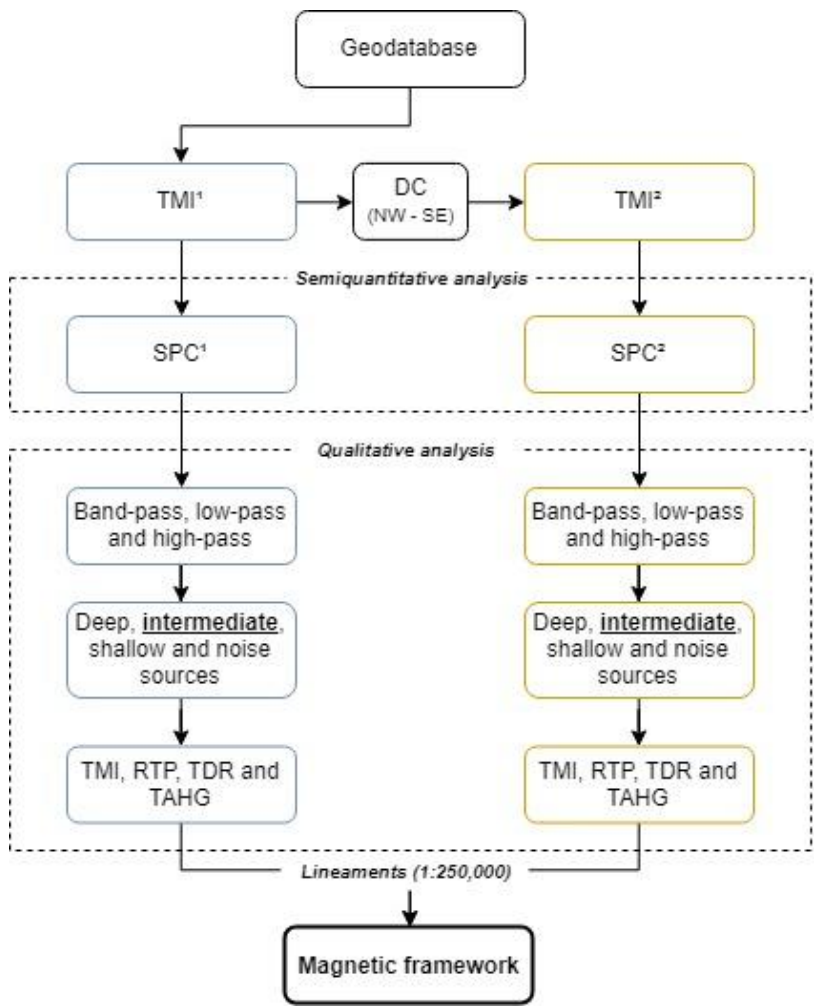

Figure 2 - Flowchart with the steps of the aeromagnetic data processing.

The lineaments were plotted on the 1:250,000 scale on the TDR maps generated from the different SPC's processed. The Datum used was the SIRGAS 2000 UTM 22s. The traces were systematically compared with the TAHG map to avoid overestimation of the lineaments, considering the different enhancements that TDR and TAHG represent, respectively, at the centers and edges of the magnetic bodies.

\section{Results and Discussions}

The mean and median values of the depth of the tubular wells were $104.21 \mathrm{~m}$ and $90.0 \mathrm{~m}$, respectively. The maximum value (above the third quartile) is $330 \mathrm{~m}$, that is, on the order of three hundreds of meters only.

The sources were separated into "deep", "intermediate", "shallow", "partial noise" and "total noise" from the SPC 1 (Figure 3). However, the deep sources were discarded from the analysis because of inadequate structural representativeness (far too depp features). Shallow sources, partial noise and total noise were also discarded due to noise excess (non-real data), making it impossible to express the magnetic sources and consequently to draw the lineaments (Figure 4). The enhancement methods were applied only to the intermediate sources grid, on which one of the lines of the guidelines was performed (Figure 5). 
The auxiliary parameters in the investigation of the sources in conjunction with the SPC ${ }^{1}$, such as wavelength, wavenumber and estimated depth, are described in Table 1. The estimated distance range for the intermediate sources of the surface down to $5 \mathrm{~km}$ depth is highlighted.

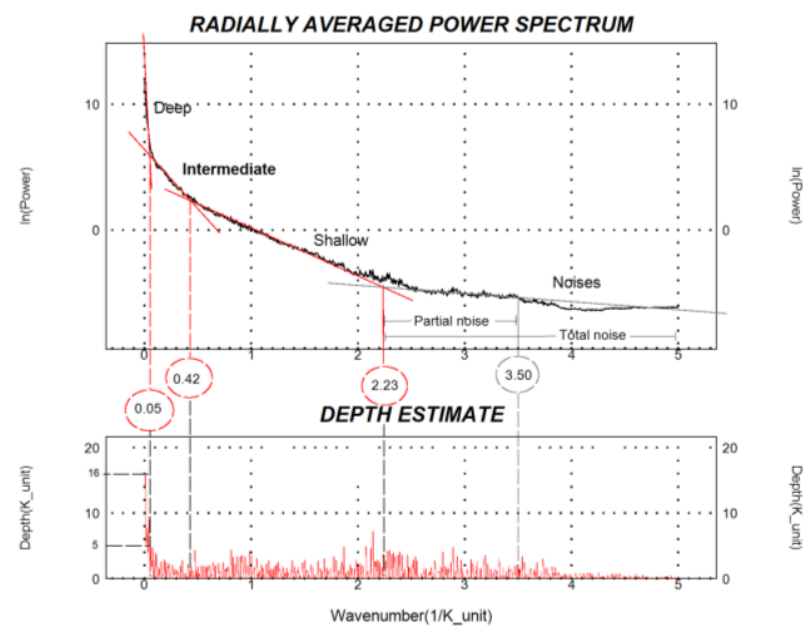

Figure 3 - First Radially Averaged Power Spectrum $\left(S P C^{1}\right)$ generated from the first Total Manetic intensity $\left(T M l^{1}\right)$. The magnetic sources were discriminated in deep, intermediate, shallow, partial noise and total noise.

Table 1 - Auxiliary parameters taken from the $S P C^{1}$ for the region.

\begin{tabular}{|c|c|c|c|}
\hline & \multicolumn{3}{|c|}{ Sources } \\
\cline { 2 - 4 } & Deep & Intermediate & Shallow \\
\hline $\begin{array}{c}\text { Wavenumber } \\
\text { (cycle/km) }\end{array}$ & $\begin{array}{c}0.00 \text { to } \\
0.05\end{array}$ & 0.05 to 0.42 & $\begin{array}{c}0.42 \text { to } \\
2.23\end{array}$ \\
\hline $\begin{array}{c}\text { Wavelength } \\
(\mathrm{m})\end{array}$ & $>20,000$ & $\begin{array}{c}20,000 \text { to } \\
2,380\end{array}$ & $\begin{array}{c}2,380 \text { to } \\
448\end{array}$ \\
\hline $\begin{array}{c}\text { Depth } \\
(\mathrm{km})\end{array}$ & 16 to 5 & 5 to 0 & 2 to 0 \\
\hline
\end{tabular}

The rose diagrams presented in Figure 5 represent the basic statistical analysis of the lineaments. Figure 5 - A represents the diagram in terms of relative frequency of length, with 6,263 lineaments and $29.55 \%$ of maximum statistical. While the Figure 5 - B show the absolute frequency, with 698 lineaments identified and $18.91 \%$ of maximum statistical. The angular intervals are $15^{\circ}$ for all rose diagrams in this work.
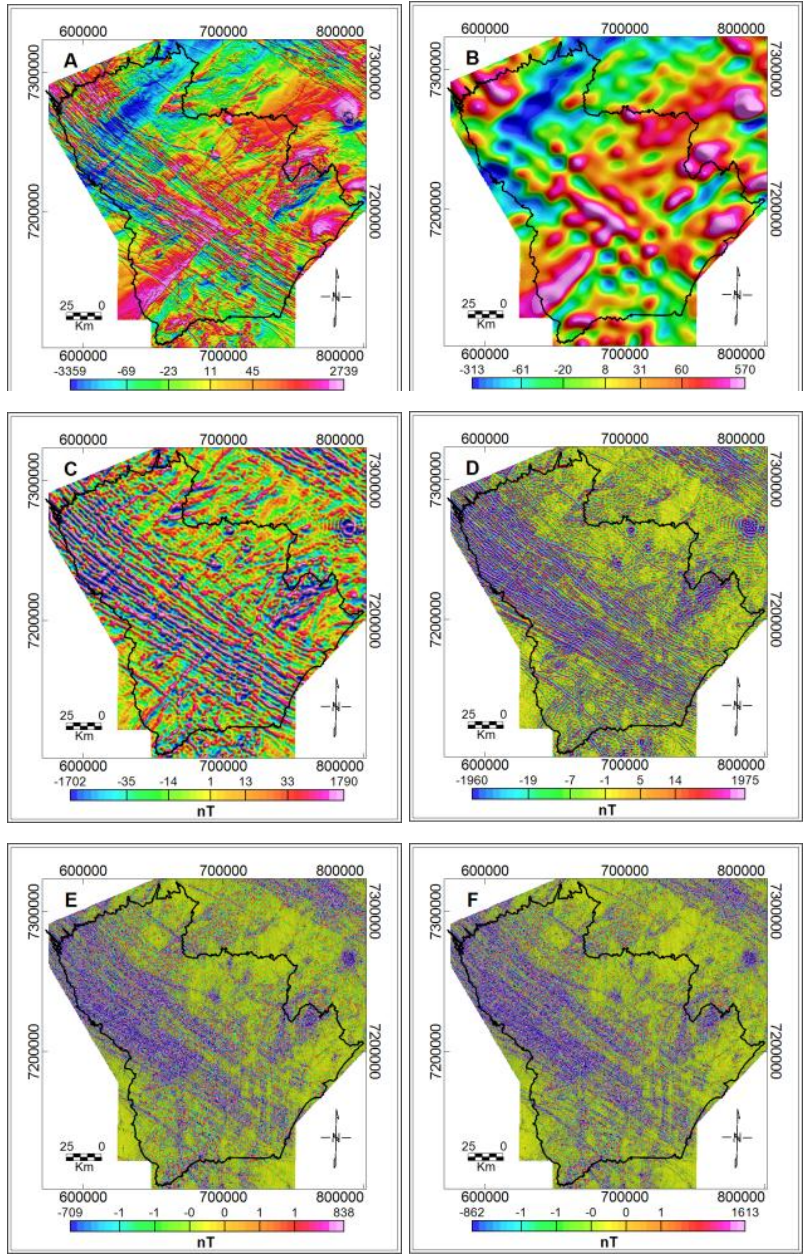

Figure 4 - Magnetic sources of the study region discriminated from the first Radially Averaged Power Spectrum (SPC $\left.{ }^{1}\right)$. A - first Total Magnetic Intensity (TMI'); $B$ - Deep sources; $C$ - Intermediate sources; $D$ - Shallow Sources; E-Partial noise; F- Total noise. 


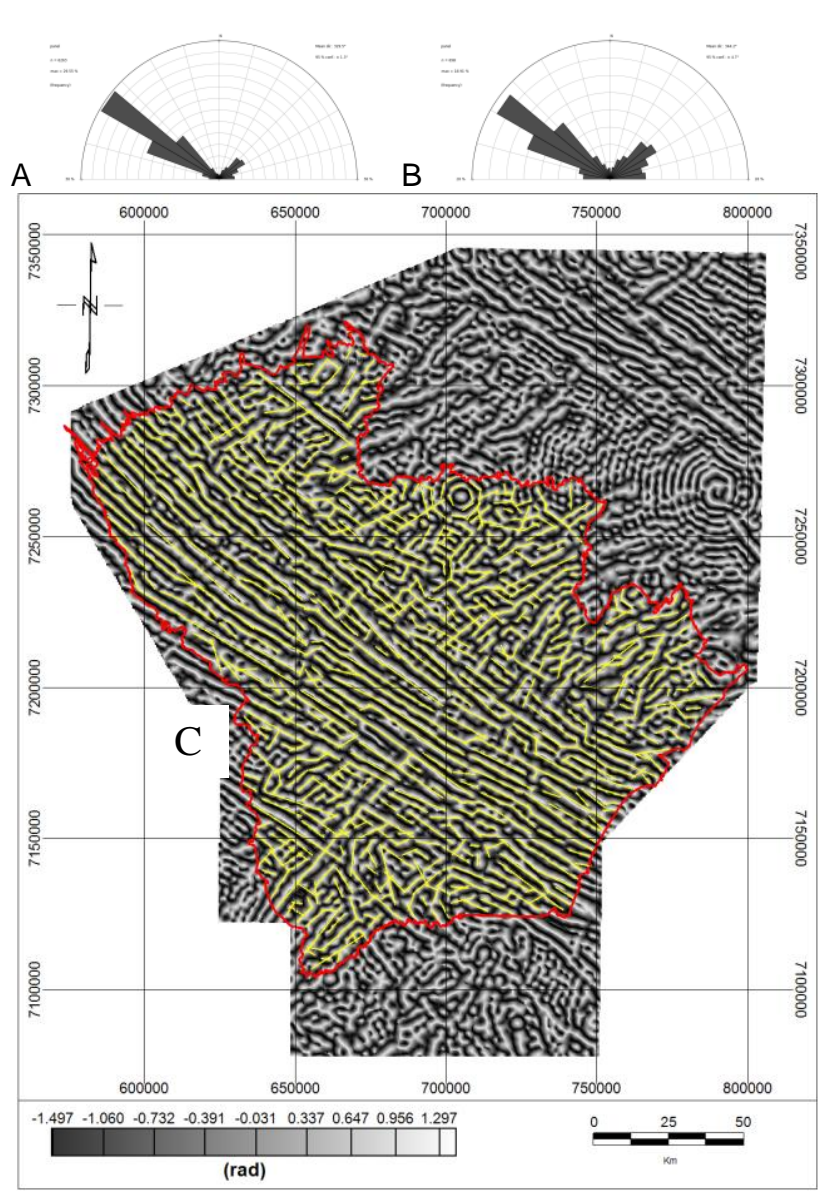

Figure 5- $A$ - Rose diagram of length; $B$ - Rose diagram of frequency; and, $C$ - Lineaments extracted from the map of the intermediate sources with the Tilt Angle filter (TDR).

Figure 6 represents the SPC${ }^{2}$. The sources were also separated into "deep", "intermediate" and "shallow", but only "intermediate" sources were used for the same reason already justified. In this step, the DC filter (Figure 7) was applied, in order to highlight the structures that were camouflaged by the Dyke Swarms from the Ponta Grossa Arch (Almeida, 1967). These dikes are of mafic composition and have high magnetization. On the other hand, the structures in other orientations are not so expressive in the maps without a NW-SE DC filter (Portela Filho \& Ferreira 2003).

The auxiliary parameters in the investigation of the sources in conjunction with the SPC ${ }^{2}$, such as wavelength, wavenumber and estimated depth, are described in Table 2. The estimated distance range for the intermediate sources goes from the surface down to 2 $\mathrm{km}$ depth.

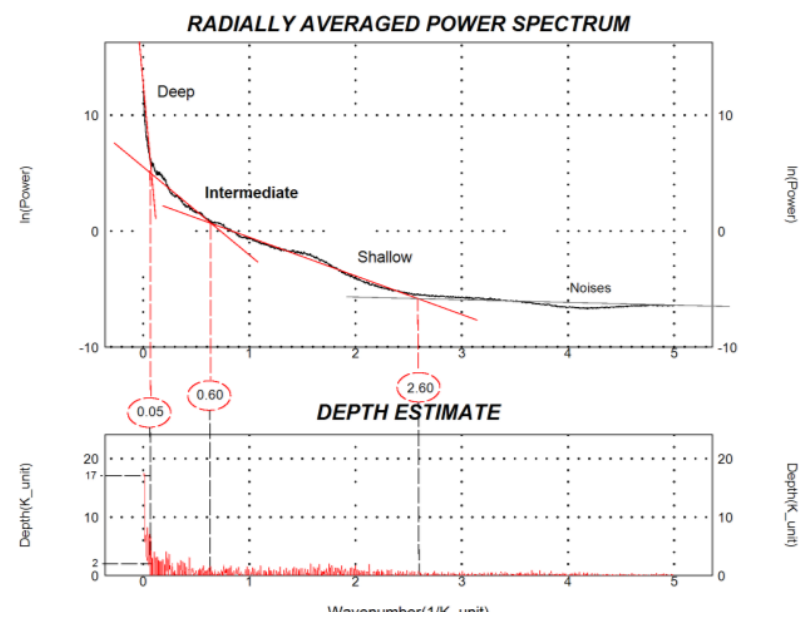

Figure 6 - Second Radially Averaged Power Spectrum (SPC $\left.{ }^{2}\right)$ generated from the second Total Magnetic Intensity $\left(T M I^{2}\right)$, filtered by Directional Cosine (DC). The magnetic sources were discriminated in deep, intermediate, shallow and noises.

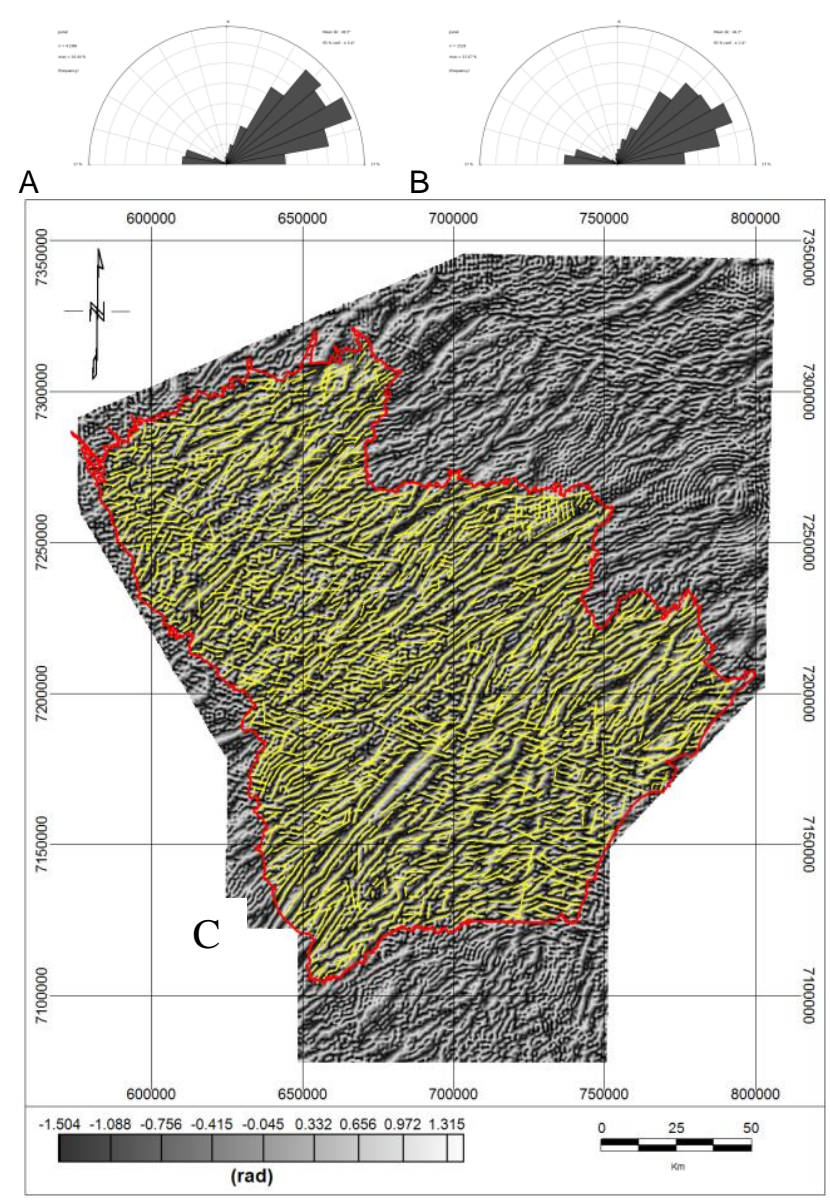

Figure 7-A - Rose diagram of length; $B$ - Rose diagram of frequency; and, $C$ - Lineaments extracted from the map of the intermediate sources with the Tilt Angle (TDR) and Directional Cosine (DC) filters. 
The rose diagrams generated in Figure 7 are: a) the relative length frequency, with 41,386 lineaments and $16.44 \%$ of maximum statistical; b) the absolute frequency, with 1,526 identified lineaments and $15.07 \%$ of maximum statistical.

Tabela 2 - Auxiliary parameters taken from the $S P C^{2}$ for the region.

\begin{tabular}{|c|c|c|c|}
\hline & \multicolumn{3}{|c|}{ Sources } \\
\cline { 2 - 4 } & Deep & Intermediate & Shallow \\
\hline $\begin{array}{c}\text { Wavenumber } \\
\text { (cycle/km) }\end{array}$ & $\begin{array}{c}0.00 \text { to } \\
0.05\end{array}$ & 0.05 to 0.60 & $\begin{array}{c}0.60 \text { to } \\
2.60\end{array}$ \\
\hline $\begin{array}{c}\text { Wavelength } \\
(\mathrm{m})\end{array}$ & $>20,000$ & $\begin{array}{c}20,000 \text { to } \\
1,666\end{array}$ & $\begin{array}{c}1,666 \text { to } \\
384\end{array}$ \\
\hline $\begin{array}{c}\text { Depth } \\
(\mathrm{km})\end{array}$ & 17 to 2 & 2 to 0 & 1 to 0 \\
\hline
\end{tabular}

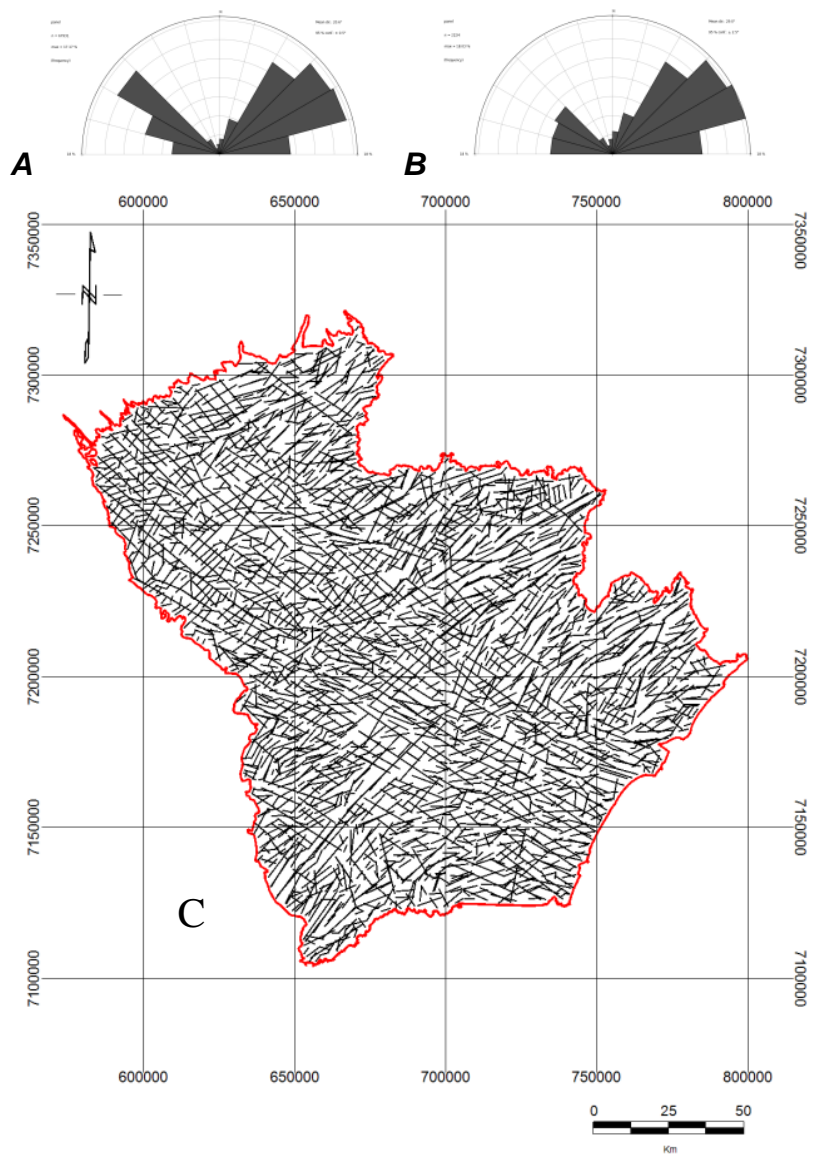

Figure 8- $A$ - Rose diagram of length; $B$ - Rose diagram of frequency; and, $C$ - Magnetic framework of Crystalline Basement Aquifer.

At the end, the lineaments were integrated, generating a magnetic framework for the aquifer region, as show in Figure 8 . The generated rose diagrams are: a) the relative length frequency, with 67,931 lineaments and $17.17 \%$ of maximum statistical; b) the absolute frequency, with 2,224 identified lineaments and $18.03 \%$ of maximum statistical.

\section{Conclusions}

Because the deep sources represent geological structures in the tens of kilometers range, there is no coherence with the level of well's water entrances. On the other hand, the shallow sources have representativeness to geological structures associated to water entrance's detphs, but the resulted map is too noisy, making it difficult to trace the lineaments in real fact data. Therefore, the choice of intermediate sources was satisfactory by complementing the gaps of the two items above, both in terms of depth and low noise level.

The chosen enhancement methods (TDR and TAHG) also collaborated in this sense, since they, respectively, highlighted centers and edges of the sources to help trace the linear magnetic gradients. The use of DC contributed to the understanding of the different depths observed in the tables 1 and 2 for the intermediate sources.

According to the visual analysis of the lineaments and evaluation of the rose diagrams generated for each lineaments map, we verify that the lineaments needed to be integrated in order to have a more complete final product. Lineaments extracted from SPC ${ }^{1}$ and SPC ${ }^{2}$ maps, area partially the same, but there were structures not presented in each other. On the other hand, this also does not guarantee that there was no overestimation of lineaments in another direction than NW-SE (removed with the DC filter). Even so, the work routine was attractive and coherent from a geophysical and geological rationale.

We plan to conduct quantitative depth analyzes to validate the lineaments' dephts stipulated in this work, as well as analyze the geospatial association and well's productivity.

\section{Acknowledgements}

The authors are grateful to Geologic Survey of Brazil (CPRM) for providing the airborne magnetic data, to Laboratory for Research in Applied Geophysics (LPGAUFPR) for the license of the program, the Laboratory for Hydrogeological Research (LPH) for guidance and structure and for the Coordination of Improvement of Higher Education Personnel (CAPES) for the financial assistance, through the scholarship of masters

\section{References}

ALMEIDA, F. F. M. Origem e evolução da Plataforma Brasileira. Boletim do DNPM-DGM. Rio de Janeiro, n. 241, 1-36p, 1967.

BASEI, M. A. S., SIGA Jr., O., MACHIAVELLI, A., MANCINI F. Evolução tectônica dos terrenos entre os cinturões Ribeira e Dom Feliciano (PR-SC). Revista Brasileira de Geociências, São Paulo, v. 22, $n^{\circ} 2$, 212-227p, 1992.

CPRM - Serviço Geológico do Brasil. Projeto Aerogeofísico Paraná - Santa Catarina: relatório final do levantamento e processamento dos dados magnetométricos e gamaespectrométricos. Lasa prospecções, 326p, 2011. 
CURY, L. F. Geologia do Terreno Paranaguá. Tese de Doutorado. Pós-Graduação em Geoquímica e Geotectônica, Instituto de Geociências. Universidade de São Paulo, 187p, 2009.

DINIZ, J. A. O., MONTEIRO, A. B., SILVA, R. C., PAULA, T. L. F. - Manual de cartografia hidrogeológica. Recife: CPRM - Serviço Geológico do Brasil. 119p. il. http://www.cprm.gov.br/MHB/Manual_de_Cartografa_Hidr ogeologica.pdf, 2014.

FERREIRA, F. J. F., SOUZA, J., BONGIOLO, A. B. S., CASTRO, L. G., ROMEIRO, M. A. T. Realce do gradiente horizontal total de anomalias magnéticas usando a inclinação do sinal analítico. Parte I: Aplicação a dados sintéticos. In: IV Simpósio Brasileiro de Geofísica, SBGf Brasília, Anais, p. 1-6, 2010.

FERREIRA, F. J. F., SOUZA, J., BONGIOLO, A. B. S., CASTRO, L. G. Enhancement of the total horizontal gradient of magnetic anomalies using the tilt angle. Geophysics. 78:J33J41, 2013.

GEOSOFT. Magmap - 2-D Frequency Domain Processing. Geosoft Technical Note, 34p, 2001.

GEOSOFT. Oasis Montaj Toppics in Gridding. Tutorial and User Guide, 260p, 2013.

GRANT, F. S. \& DODDS, J. MAGMAP FFT processing system development notes, Paterson Grant and Watson Limited, 1972.

$\mathrm{LI} X$. Magnetic reduction-to-the-pole at low latitudes: observations and considerations. Lead. Edge 27 (8), 9901002, 2008.

MacLEOD, I. N., VIERRA, S., CHAVES, A. C. Analytic signal and reduction-to-the-pole in the interpretation of total magnetic field data at low magnetic latitudes. Proceedings of the third international congress of the Brazilian Society of Geophysicists, 1993.

MILLER, H. G. \& SINGH, V. Potential field tilt - a new concept for location of potential field sources. Journal of Applied Geophysics, 32(2-3): 213-217, 1994.

MINISTÉRIO DE MEIO AMBIENTE -
Recursos Hecretaria de
Urbano. Carta das Águas Subterrâneas do Paraná.
Brasília,
http://www.aguasparana.pr.gov.br/modules/conteudo/cont
eudo.php?conteudo=79, 2015 .

PORTELA FILHO, C. V., FERREIRA, F. J. F. Processamento e interpretação de dados aeromagnéticos da região central do Arco de Ponta Grossa (Bacia do Paraná). $8^{\text {th }}$ International Congress of the Brazilian Geophysical Society (In Portuguese), 2003.

SALAMUNI, E. Tectônica da Bacia Sedimentar de Curitiba (PR). Tese de Doutorado. Pós-Graduação em Geociências, Instituto de Geociências e Ciências Exatas. Universidade Estadual Paulista, 214p, 1998.

SIGA JR., O., BASEI, M. A. S., REIS NETO, J. M., MACHIAVELLI, A., HARARA, O. M. O Complexo Atuba: um cinturão Paleoproterozóico intensamente retrabalhado no Neoproterozóico. Boletim IGUSP: Série Científica, v. 26, 69-98p, 1995.

SOUZA FILHO, O. A. DE, SILVA, A. M., McCAFFERTY, A., PERROTTA, M. M. The Use of Airborne Magnetics in Hydrogeology: An Example from Northeast Brazil. In: XI Intl.Congr. Braz. Geophys. Soc., SBGf, Salvador, 2009. 